\title{
Location, structure, and function of the target of a transcriptional activator protein
}

\author{
Hong Tang, ${ }^{1}$ Konstantine Severinov, ${ }^{2}$ Alex Goldfarb, ${ }^{2}$ David Fenyo, ${ }^{3}$ Brian Chait, ${ }^{3}$ \\ and Richard H. Ebright ${ }^{1,4}$
}

${ }^{1}$ Department of Chemistry and Waksman Institute, Rutgers University, New Brunswick, New Jersey 08855 USA; ${ }^{2}$ Public Health Research Institute, New York, New York 10016 USA; ${ }^{3}$ Laboratory for Mass Spectrometry, Rockefeller University, New York, New York 10021 USA

\begin{abstract}
We have isolated and characterized single-amino-acid substitution mutants of RNA polymerase $\alpha$ subunit defective in CAP-dependent transcription at the lac promoter but not defective in CAP-independent transcription. Our results establish that (1) amino acids 258- 265 of $\alpha$ constitute an "activation target" essential for CAP-dependent transcription at the lac promoter but not essential for CAP-independent transcription, (2) amino acid 261 is the most critical amino acid of the activation target, (3) amino acid 261 is distinct from the determinants for $\alpha$-DNA interaction, and (4) the activation target may fold as a surface amphipathic $\alpha$-helix. We propose a model for transcriptional activation at the lac promoter that integrates these and other recent results regarding transcriptional activation and RNA polymerase structure and function.
\end{abstract}

[Key Words: Transcriptional activation; RNA polymerase; CAP-dependent transcription; lac promoter]

Received August 26, 1994; revised version accepted October 26, 1994.

Escherichia coli catabolite gene activator protein (CAP) activates transcription by binding to upstream DNA sites and enhances binding and transcription initiation by RNA polymerase (RNAP) (for review, see Reznikoff 1992; Ebright 1993; Kolb et al. 1993a). CAP is a dimer of two identical subunits, each consisting of 209 amino acids. Amino acids 156-164 of the promoter-proximal subunit of the CAP constitute an "activating region" essential for transcriptional activation at the lac promoter but not essential for DNA binding by CAP and DNA bending by CAP (Bell et al. 1990; Eschenlauer and Reznikoff 1991; Zhou et al. 1993a,b; Niu et al. 1994). Alanine scanning of the activating region indicates that the side chain of Thr-158-and, apparently, the side chain of no other amino acid within the activating region-is essential for transcriptional activation at the lac promoter (Niu et al. 1994). In the structure of the CAP-DNA complex (Schultz et al. 1991), the activating region forms a prominently exposed, essentially continuous, surface with dimensions of $\sim 11 \times 14 \AA$, and Thr-158 is especially prominently exposed and located at the center of the surface. It has been proposed that transcriptional activation at the lac promoter involves protein-protein interaction between the activating region of the promoter-proximal subunit of the CAP dimer-particularly the Thr-158 side

${ }^{4}$ Corresponding author. chain of the promoter-proximal subunit of the CAP dimer-and a molecule of RNAP bound adjacent to CAP on promoter DNA (Zhou et al. 1993a,b; Niu et al. 1994).

E. coli RNAP is a multisubunit enzyme with subunit composition $(\alpha)_{2} \beta \beta \sigma$ (for review, see Burgess 1976; Chamberlin 1976; von Hippel et al. 1992). Three lines of evidence suggest that the $\alpha$ subunit contains the target for the proposed protein-protein interaction between CAP and RNAP at the lac promoter /the "activation target $\left.^{\prime \prime}\right)$. First, results of protein-protein photo-cross-linking establish that the carboxy-terminal region of $\alpha$ is in direct physical proximity to the activating region of CAP at the lac promoter (Chen et al. 1994). Second, deletion of the carboxy-terminal region of the $\alpha$ subunit lamino acids 236-329 or 257-329; Igarashi and Ishihama 1991; Kolb et al. 1993b), or substitution of amino acid 265 located within the carboxy-terminal region of $\alpha$ /Zou et al. 19921, results in an RNAP derivative defective in CAPdependent transcription at the lac promoter but not defective in CAP-independent transcription. Third, certain certain anti- $\alpha$ monoclonal antibodies strongly inhibit CAP-dependent transcription at the lac promoter but only partly inhibit CAP-independent transcription (Riftina et al. 1990; Venezia and Krakow 1990).

In this work we have defined the boundaries, critical amino acids, and properties of the activation target within $\alpha$. Our results suggest a detailed model for the structure and function of the activation target. 


\section{Results}

Amino acids 258-265 of $\alpha$ constitute an activation target essential for CAP-dependent transcription but not essential for CAP-independent transcription

We have used PCR-mediated random mutagensis (Zhou et al. 1991, 1993a) followed by application of a screen to isolate single-amino-acid substitution mutants of RNAP $\alpha$ subunit specifically defective in CAP-dependent transcription - that is, defective in CAP-dependent transcription but not defective in CAP-independent transcription. We designate such mutants $r p o A^{\text {pct, CAP }}$, where $r p o A$ denotes the gene encoding $\alpha$, pct denotes positive control defective, and CAP denotes CAP-dependent transcription. Our screen tested two phenotypes on a single agar plate: (1) defect in CAP-dependent transcription; and (2) absence of defect in CAP-independent transcription. To test phenotype 1 , the screen scored expression of the lac and $r b s$ operons. [The $l a c$ and $r b s$ operons are required for utilization of lactose and ribose, respectively (Beckwith 1978; Iida et al. 1984; Lopilato et al. 1984). The lac and rbs promoters are CAP-dependent promoters with identical distances between the center of the DNA site for CAP and the transcription start point (61.5 bp) but with different -35-region and - 10-region sequences (Dickson et al. 1977; Bell et al. 1986; Zhou et al. 1993a).] To test phenotype 2 , the screen scored viability. Mutants lacking CAP are viable on rich media (Sabourin and Beckwith 1974). Therefore, we reasoned that mutants of $\alpha$ specifically defective in CAP-dependent transcription would be viable on rich media. In contrast, we reasoned that mutants of $\alpha$ defective in both CAP-dependent and CAP-independent transcription would be inviable or would exhibit significantly reduced growth rates.

To facilitate mutagenesis and screening, the screen was performed in strains containing mutagenized rpoA gene on a multicopy plasmid and wild-type $r p o A$ gene on the chromosome. Immunoblotting with anti- $\alpha$ antibody indicated that under the conditions of the screen plasmid-encoded $\alpha$ was overproduced $\sim 2.5$-fold relative to chromosome-encoded $\alpha$ (see Materials and methods). Based on this level of overproduction, assuming equal efficiencies of assembly into RNAP of plasmid-encoded $\alpha$ and chromosome-encoded $\alpha$, it was expected that $\sim 90 \%$ of RNAP would have at least one plasmid-encoded $\alpha$ subunit, and $\sim 50 \%$ of RNAP would have two plasmid-encoded $\alpha$ subunits. [For one plasmid-encoded $\alpha$ derivative, $[\mathrm{Gly}-261] \alpha$, we have verified directly that this level of overproduction and asembly into RNAP occurs, by isolation of RNAP followed by two-dimensional electrophoresis/isoelectric-focusing (data not shown).] Therefore, it was expected that the phenotype of plasmid-encoded $\alpha$ would be dominant or partly dominant.

Plasmids containing mutagenized $r p o A$ structural gene were introduced by transformation into $\mathrm{lac}^{+} \mathrm{rbs}^{+}$ $r p o A^{+}$tester strains, and transformants were plated to double-sugar lactose/ribose/tetrazolium/ampicillin indicator agar. RpoA ${ }^{\text {pct,CAP }}$ clones were identified as red colonies ( $\mathrm{Lac}^{-} \mathrm{Rbs}^{-}$; viable). Two tester strains were used: XE54 (thi) and XE4 (Agal165 thi). XE54 required a strong $\mathrm{Lac}^{-}$phenotype to yield red colonies on lactose/ ribose/tetrazolium/ampicillin indicator agar and, therefore, permitted a stringent screen. Because of $\Delta$ gal165 marker, XE4 required only a moderate $\mathrm{Lac}^{-}$phenotype to yield red colonies on lactose/ribose/tetrazolium/ ampicillin indicator agar and, therefore, permitted a less stringent screen (cf. Ebright et al. 1984). Sixty-five independent mutagenesis reactions were performed, and $\sim 30,000$ mutagenized transformants were screened in each tester strain (Table 1). From these, 11 independent $r p o A^{\mathrm{pct}, \mathrm{CAP}}$ candidate clones were identified in highstringency-screen strain XE54, and 10 independent $r p o A^{\text {pct,CAP }}$ candidate clones were identified in lowstringency-screen strain XE4 (Table 1).

For each candidate $r p o A^{\mathrm{pct}, \mathrm{CAP}}$ clone, plasmid DNA was prepared and introduced by transformation into strains XE54 (thi) and XE56 (lacPL8-UV5 thi), and CAPdependent transcription at the lac promoter and CAPindependent transcription at the 1aCPL8-UV5 promoter were assessed in quantitative in vivo assays. [The lacPL8-UV5 promoter is a CAP-independent derivative of the lac promoter (Silverstone et al. 1970; Beckwith et al. 1972; Arditti et al. 1973); the 1acPL8-UV5 promoter contains a substitution in the DNA site for CAP and two substitutions in the -10 region (Gilbert 1976; Dickson et al. 1977). The results confirmed that all 21 candidate rpo $A^{\text {pct,CAP }}$ clones were defective in CAP-dependent transcription at the lac promoter /two- to threefold; Fig. 1A) but not defective in CAP-independent transcription (Fig. 1B).

For each of the $21 \mathrm{rpo}^{\mathrm{pct}, \mathrm{CAP}}$ mutants, the substitution responsible for the phenotype was mapped by marker rescue using $\mathrm{XbaI}-\mathrm{HindIII}$ and HindIII-BamHI rpo $A$ DNA fragments, which contain codons 1-229 and $230-329$, respectively. In each case, the nucleotide substitution responsible for the phenotype mapped to codons 230-329. For each mutant, the nucleotide sequence of codons 230-329 was determined, and the amino acid sequence of the $\alpha$ derivative was inferred.

Remarkably, the amino acid substitutions in the 21 $r p o A^{\text {pct,CAP }}$ mutants mapped to a single 8-amino-acid region of $\alpha$-that is, amino acids $258-265$ (Table 2). One substitution was obtained at amino acid 258 ; two substitutions were obtained at amino acid $261_{\text {; }}$ one substitution was obtained at amino acid 264; and one substitution was obtained at amino acid 265 (Table 2). Substitutions at amino acid 265 (Arg-265 $\rightarrow$ Cys and Arg-265 $\rightarrow$ His) have been shown previously to reduce CAP-dependent transcription at the lac promoter (Zou et al. 1992). The fact that we have reisolated a substitution at amino acid 265 confirms the importance of this amino

Table 1. Random mutagenesis and screen

\begin{tabular}{lr}
\hline Mutagenesis reactions & 65 \\
Total candidates (XE54) & 33,000 \\
Lac $^{-}$Rbs & candidates (XE54) \\
Total candidates (XE4) & 11 \\
Lac $^{-}$Rbs $^{-}$candidates (XE4) & 27,000 \\
\hline
\end{tabular}



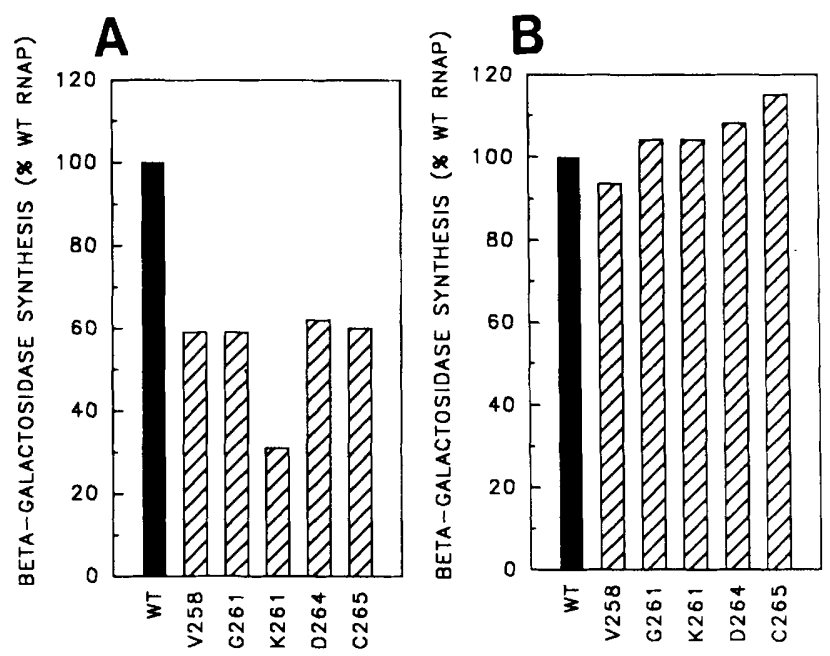

Figure 1. Transcription in vivo. (A) CAP-dependent transcription at the lac promoter; $(B)$ CAP-independent transcription at the lacPL8-UV5 promoter.

acid for CAP-dependent transcription at the lac promoter. The fact that we also have isolated substitutions at amino acids 258,261 , and 264 indicates for the first time the importance of these amino acids for CAP-dependent transcription at the lac promoter. We conclude that amino acids 258-265 constitute a region of $\alpha$ that is essential for CAP-dependent transcription at the lac and $r b s$ promoters but not essential for CAP-independent transcription. We designate this region the activation target.

The statistics of the analysis are informative. In the high-stringency screen (the screen using strain XE54), we obtained 11 independent mutants substituted at amino acid 261 and no mutants substituted at any other amino acid. These statistics indicate that the high-stringency screen has approached, or reached, saturation of available targets. That is, these statistics indicate that there are few, or no, other amino acids at which a substitution obtainable by a single-base-pair change can confer a RpoA ${ }^{\text {pct, CAP }}$ phenotype able to pass the high-stringency screen. We propose that amino acids $258-265$ constitute the only region of $\alpha$ that is essential for CAP-dependent transcription at the $l a c$ and $r b s$ promoters but not essential for CAP-independent transcription.
The side chain of amino acid 261 of $\alpha$ is essential for CAP-dependent transcription

To define individual side-chain determinants for CAPdependent transcription at the $l a c$ and $r b s$ promoters, we performed an alanine scan (Cunningham and Wells 1989) of the activation target and 8 flanking amino acids. Alanine scanning has three distinct advantages for identification of individual side-chain determinants for proteinprotein interaction (see Cunningham and Wells 1989, 1993; Wells 1991; Jin et al. 1992; Kelley and O'Connell 1993; Niu et al. 1994): First, alanine scanning yields a comprehensive set of substitutions, including both phenotypically positive and negative substitutions. Second, alanine scanning yields a chemically consistent set of substitutions. Third, and most important, alanine scanning yields side-chain truncation substitutions; alanine substitution eliminates all side-chain atoms beyond $C \beta$, and all interactions made by side-chain atoms beyond $\mathrm{C} \beta$.

We used site-directed mutagenesis to substitute each amino acid from 255 to 270 of $\alpha$, one-by-one, by alanine. For each resulting $\alpha$ derivative, we then assessed CAPdependent transcription at the $l a c$ and $r b s$ promoters in vivo. The results are presented in Table 3 . Alanine substitution of Glu-261 resulted in a large defect in CAPdependent transcription at the $l a c$ and $r b s$ promoters (as large a defect as Gly or Lys substitution; cf. Tables 2 and 3). Alanine substitution of Asp-258 or Asp-259 resulted in a small, but reproducible, defect. Strikingly, alanine substitution of no other amino acid resulted in a defect.

We conclude that for Glu-261, side-chain atoms beyond $\mathrm{C} \beta$ are critical for CAP-dependent transcription at the $l a c$ and $r b s$ promoters. We conclude that for Asp-258 and Asp-259, side-chain atoms beyond $C \beta$ are important for CAP-dependent transcription at the lac and rbs promoters but, quantitatively, at a lower level of importance. Finally, we conclude that Glu-261, Asp-258, and Asp-259 are the only amino acids of the activation target for which side-chain atoms beyond $C \beta$ are important for CAP-dependent transcription at the $l a c$ and $r b s$ promoters. In the random-mutagenesis analysis of the preceding section, substitutions at two other amino acids were shown to result in defects in transcriptional activation at the $l a c$ and $r b s$ promoters-that is, Val-264 $\rightarrow$ Asp and Arg-265 $\rightarrow$ Cys (Table 2; see also Zou et al. 1992). Based on the alanine-scanning analysis of this section, we sug-

Table 2. Sequences and phenotypes of $\mathrm{rpoa}^{\text {pct,CAP }}$ mutants

\begin{tabular}{llcccc}
\hline $\begin{array}{l}\text { Amino acid } \\
\text { substitution }\end{array}$ & $\begin{array}{l}\text { Codon } \\
\text { substitution }\end{array}$ & $\begin{array}{l}\text { Number of } \\
\text { isolates, (XE54) }\end{array}$ & $\begin{array}{l}\text { Number of } \\
\text { isolates (XE4) }\end{array}$ & $\begin{array}{l}\text { CAP-dependent } \\
\text { transcription }(\text { Iac) }\end{array}$ & $\begin{array}{l}\text { CAP-dependent } \\
\text { transcription }(r b s)^{a}\end{array}$ \\
\hline None & None & - & - & ++++ \\
$258 \mathrm{Asp} \rightarrow$ Val & GAC $\rightarrow$ GTC & - & 1 & ++ \\
$261 \mathrm{Glu} \rightarrow$ Gly & GAA $\rightarrow$ GGA & 4 & 1 & + \\
$261 \mathrm{Glu} \rightarrow$ Lys & GAA $\rightarrow$ AAA & 7 & 1 & + \\
$264 \mathrm{Val} \rightarrow$ Asp & GTC $\rightarrow$ GAC & - & 1 & +++ \\
$265 \mathrm{Arg} \rightarrow$ Cys & CGC $\rightarrow$ TGC & - & +++ & + \\
+
\end{tabular}

${ }^{a}$ Colony colors of XE54 pREII $\alpha$ and derivatives on tetrazolium indicator agar. $(++++\mid$ White; $(-)$ dark red. 
Table 3. Alanine scanning

\begin{tabular}{lcc}
\hline $\begin{array}{l}\text { Amino acid } \\
\text { substitution }\end{array}$ & $\begin{array}{c}\text { CAP-dependent } \\
\text { transcription (lac) }\end{array}$ & $\begin{array}{c}\text { CAP-dependent } \\
\text { transcription }(\mathrm{rbs})^{\mathrm{a}}\end{array}$ \\
\hline None & ++++ & ++++ \\
$255 \mathrm{Arg} \rightarrow \mathrm{Ala}$ & ++++ & ++++ \\
$256 \mathrm{Pro} \rightarrow \mathrm{Ala}$ & ++++ & ++++ \\
$257 \mathrm{Val} \rightarrow \mathrm{Ala}$ & ++++ & ++++ \\
$258 \mathrm{Asp} \rightarrow \mathrm{Ala}$ & ++ & + \\
$259 \mathrm{Asp} \rightarrow \mathrm{Ala}$ & ++ & ++ \\
$260 \mathrm{Leu} \rightarrow \mathrm{Ala}$ & ++++ & + \\
$261 \mathrm{Glu} \rightarrow \mathrm{Ala}$ & - & ++++ \\
$262 \mathrm{Leu} \rightarrow \mathrm{Ala}$ & ++++ & ++++ \\
$263 \mathrm{Thr} \rightarrow \mathrm{Ala}$ & ++++ & +++ \\
$264 \mathrm{Val} \rightarrow$ Ala & ++++ & ++++ \\
$265 \mathrm{Arg} \rightarrow \mathrm{Ala}$ & ++++ & ++++ \\
$267 \mathrm{Ala}$ & ++++ & ++++ \\
$266 \mathrm{Ser} \rightarrow \mathrm{Ala}$ & ++++ & ++++ \\
$268 \mathrm{Asn} \rightarrow \mathrm{Ala}$ & ++++ & ++++ \\
$269 \mathrm{Cys} \rightarrow$ Ala & ++++ & ++ \\
$270 \mathrm{Leu} \rightarrow$ Ala & ++++ & ++ \\
\hline
\end{tabular}

${ }^{a}$ Colony colors of XE54 pHTfl $\alpha$ and derivatives on tetrazolium indicator agar.

gest that the Val-264 $\rightarrow$ Asp and Arg-265 $\rightarrow$ Cys substitutions affect CAP-dependent transcription indirectly, by introducing non-native side-chains atoms that disrupt the activation target sterically, electrostatically, or conformationally.

The fact that the activation target has only a small number of critical amino acids is reminiscent of the patterns observed with functional epitopes for protein-antibody and protein-receptor interaction /Cunningham and Wells 1989, 1993; Jin et al. 1992; Kelley and O'Connell 1993) and, most important, reminiscent of the pattern observed with the activating region of CAP (Niu et al. 1994).

\section{Amino acid 261 of $\alpha$ is essential for CAP-dependent transcription in vitro}

To confirm and quantify the in vivo results, we performed in vitro transcription experiments with wildtype RNAP and with RNAP derivatives containing [Gly$261] \alpha$ and [Lys-261] $\alpha$. To prepare mutant RNAP substantially free of contaminating wild-type $\alpha$, we subcloned the genes encoding [Gly-261] $\alpha$ and [Lys-261] $\alpha$ into T7 RNA polymerase expression vector pET3a (Studier et al. 1990), overproduced [Gly-261] $\alpha$ and [Lys-261] $\alpha$ to the extent of $\sim 30 \%$ of total cell protein, purified [Gly-261] $\alpha$ and [Lys-261] $\alpha$, and reconstituted mutant RNAP from purified mutant $\alpha$ and purified wild-type $\beta, \beta^{\prime}$, and $\sigma$ (see Zalenskaya et al. 1990; Borukhov and Goldfarb 1993). Results of MALDI mass spectrometry (Fig. 2) and twodimensional electrophoresis/isoelectric-focusing /data not shown) established that each purified mutant $\alpha$ and each reconstituted mutant RNAP contained $\leqslant 10 \%$ contaminating wild-type $\alpha$.

To analyze CAP-dependent transcription, we performed abortive initiation in vitro transcription experi- ments with the lac promoter. To analyze CAP-independent transcription, we performed abortive initiation in vitro transcription experiments with the lacPUV5 promoter (Silverstone et al. 1970; Beckwith et al. 1972; Arditti et al. 1973; Malan et al. 1984). The results are presented in Figure 3. Each mutant RNAP was defective in CAP-dependent transcription at the lac promoter. The mutant RNAP containing [Gly-261] $\alpha$ was $\sim 5$-fold defective; the mutant RNAP containing [Lys-261] $\alpha$ was $\sim 10$ fold defective. In contrast, each mutant RNAP was fully functional in CAP-independent transcription at the lacPUV5 promoter. We conclude that amino acid 261 of $\alpha$ is essential for CAP-dependent transcription at the lac promoter but not essential for CAP-independent transcription, both in vivo and in vitro.

\section{Amino acid 261 of $\alpha$ is not essential for $\alpha-D N A$ interaction in vitro}

Recently, it has been shown that RNAP $\alpha$ is a sequencespecific DNA-binding protein involved directly in promoter recognition (Ross et al. 1993; Blatter et al. 1994). RNAP $\alpha$ recognizes a 15-bp adenine/thymine-rich DNA sequence present immediately upstream of the -35 region in certain strong promoters, notably the $\operatorname{rrn} B \mathrm{P} 1$ promoter, but absent in the lac promoter (the upstream element or UP element; Ross et al. 1993; Rao et al. 1994).
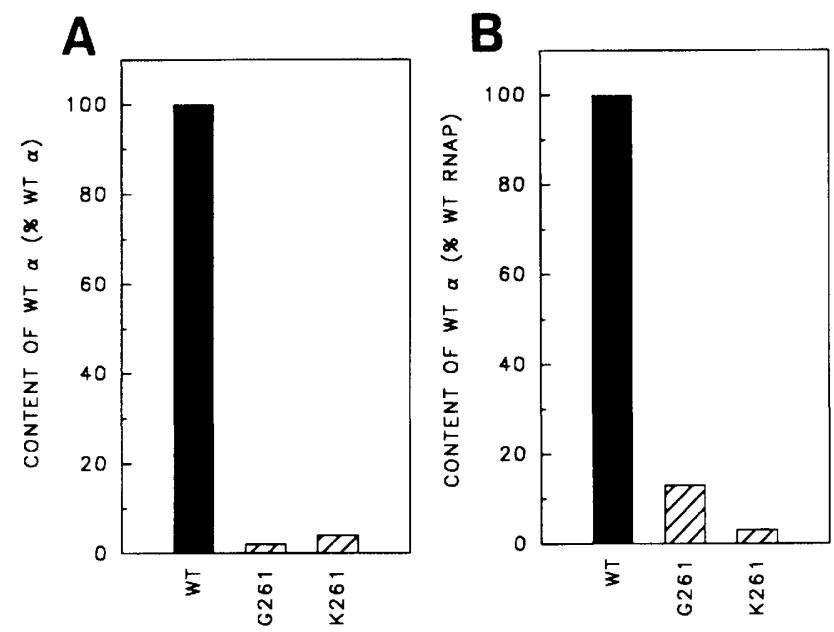

Figure 2. Purities of $\alpha$ derivatives and RNAP derivatives. Data are from endoproteinase Glu-C digestions followed by MALDI mass spectrometry. Peptide $\alpha(230-261)$ (molecular mass, 3805 daltons) is produced upon endoproteinase Glu-C digestion of wild-type $\alpha$, but not upon endoproteinase Glu-C digestion of $[$ Gly-261] $\alpha$ and [Lys-261] $\alpha$ and, therefore, is diagnostic of the presence of wild-type $\alpha$. Control peptide $\alpha(289-319)$ (molecular mass, 3379 daltons) is produced upon endoproteinase Glu-C digestion of wild-type $\alpha,[G l y-261] \alpha$, and [Lys-261] $\alpha$. Data are ratios of peptide $\alpha(230-261)$ to control peptide $\alpha(289-319)$, normalized to values with homogeneous wild-type $\alpha$ or homogeneous wild-type RNAP. (A) Wild-type $\alpha$, [Gly-261] $\alpha$, and [Lys$261 \mid \alpha_{;}(B)$ wild-type RNAP, [Gly-261] $\alpha$-RNAP, and [Lys-261] $\alpha-$ RNAP. 


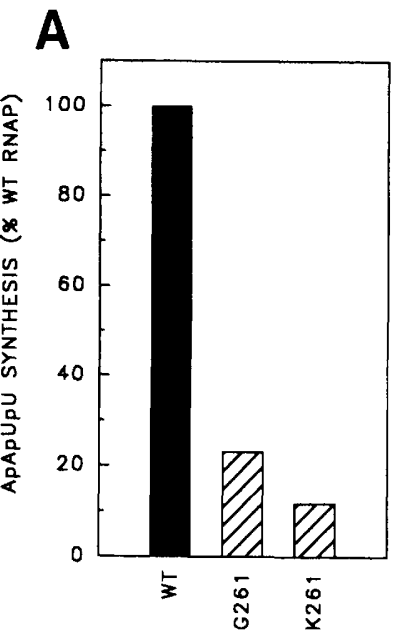

\section{B}

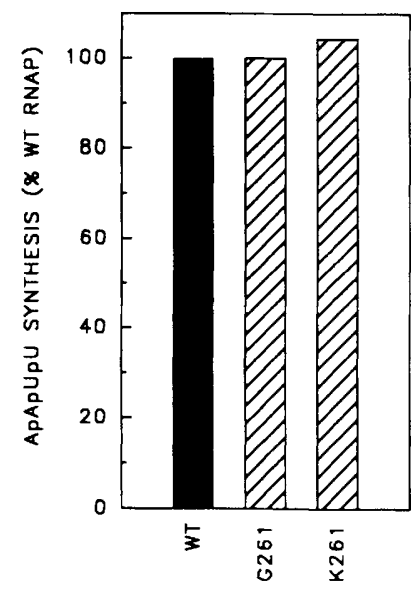

Figure 3. Transcription in vitro. $(A)$ CAP-dependent transcription at the lac promoter (150 nM RNAP or derivative, $40 \mathrm{~nm}$ CAP); (B) CAP-independent transcription at the lacPUV5 promoter (150 nM RNAP or derivative, $0 \mathrm{nM}$ CAP).

The determinants for $\alpha-\mathrm{DNA}$ interaction are contained within amino acids $245-329$ of $\alpha$.

As a first step in defining the relationship between activation target function and $\alpha-$ DNA interaction, we assessed the effect of substitution of the most critical amino acid of the activation target-amino acid 261 -on $\alpha$-DNA interaction. We performed electrophoretic mobility shift DNA-binding experiments using a 19-bp DNA fragment containing a specific DNA site for $\alpha$ (positions -57 to -47 of the $\operatorname{rrn} B \mathrm{P} 1$ promoter) and using purified wild-type $\alpha,[\mathrm{Gly}-261] \alpha$, and [Lys-261] $\alpha$. The results are presented in Figure 4 and Table 4. Wild-type $\alpha$ binds to the DNA fragment with an apparent equilibrium binding constant of $2.1 \times 10^{5} / \mathrm{M}^{-1}$. [Gly-261] $\alpha$ and [Lys-261] $\alpha$ exhibit apparent equilibrium binding constants equal to, or slightly higher than, that of wild-type $\alpha$. Consistent with the absence of a negative effect of substitution of amino acid 261 on $\alpha$-DNA interaction in vitro, we find that substitution of amino acid 261 has little or no negative effect on upstream-element-dependent transcription at the $\operatorname{rrn} B$ P1 promoter in vivo ( $\mathrm{T}$. Gaal, W. Ross, R. Gourse, H. Tang, and R. Ebright, unpubl.). We conclude that amino acid 261 is not essential for $\alpha$-DNA interaction. We conclude further that amino

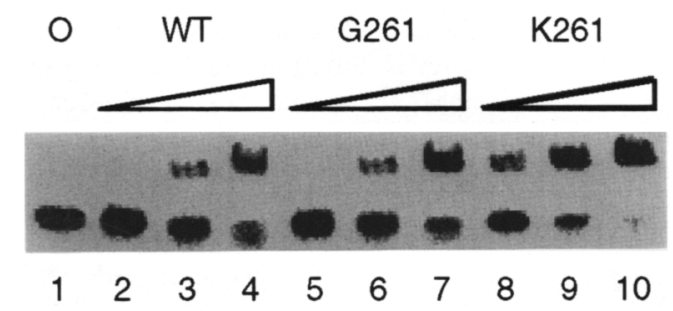

Figure 4. $\alpha$-DNA interaction in vitro. (Lane 1) No $\alpha_{\text {; }}$ (lanes $2-4$ ) $1.25,2.5$, and $5 \mu \mathrm{M}$ wild-type $\alpha$; (lanes 5-7) $1.25,2.5$, and $5 \mu \mathrm{M}$ $\left[\right.$ Gly-261] $\alpha_{;}$(lanes 8-10) 1.25, 2.5, and $5 \mu \mathrm{M}$ [Lys-261] $\alpha$.
Table 4. $\alpha-D N A$ interaction in vitro

\begin{tabular}{|c|c|}
\hline Protein & $K_{\text {app }}\left(\mathrm{M}^{-1}\right)^{\mathrm{a}}$ \\
\hline$\alpha$ & $2.1( \pm 0.7) \times 10^{5}$ \\
\hline$[$ Gly-261] $\alpha$ & $2.2( \pm 0.7) \times 10^{5}$ \\
\hline$[$ Lys-261] $\alpha$ & $6.3( \pm 0.4) \times 10^{5}$ \\
\hline
\end{tabular}

${ }^{a}$ Mean \pm 1 S.D.

acid 261 of $\alpha$ is distinct from the determinants for $\alpha-$ DNA interaction.

\section{Discussion}

\section{Structure of the activation target}

Previous work has established that RNAP $\alpha$ consists of (1) an independently folded, independently dimerized amino-terminal domain containing determinants for interaction with the remainder of RNAP, (2) an independently folded, independently dimerized, carboxy-terminal domain containing determinants for interaction with DNA, and $(3)$ an unstructured and/or flexible interdomain linker (Hayward et al. 1991; Igarashi et al. 1991; Kolb et al. 1993b; Ross et al. 1993; Blatter et al. 1994). The activation target defined in this work (amino acids $258-265$ ) is located entirely within the $\alpha$ carboxy-terminal domain (amino acids 249-329).

No high-resolution information is available regarding the structure of the $\alpha$ carboxy-terminal domain. Nevertheless, because 4 of the 5 amino acids at which substitutions conferring an RpoA ${ }^{\text {pct,CAP }}$ phenotype were obtained are charged amino acids-that is, Asp-258, Asp259, Glu-261, and Arg-265-we predict that the side chains of these amino acids are exposed to solvent on the surface of RNAP and are available to interact with other molecules. [The side chains of $80 \%$ of Asp residues, $80 \%$ of Glu residues, and $>90 \%$ of Arg residues are solvent exposed in globular proteins (Chothia 1976; Janin 1979).] We note further that Arg-265 is the target for bacteriophage T4 ADP ribosylation of RNAP (for review, see Goff 1984). We infer that the side chain of this amino acid is sufficiently exposed on the surface of RNAP to interact with 70,000- and 26,000-dalton enzymes [the products of the bacteriophage T4 alt and mod genes (Goff 1984)].

Circular dichroism spectroscopy indicates that the $\alpha$ carboxy-terminal domain contains $\sim 40 \% \alpha$-helix and $\sim 0 \% \beta$-sheet (Blatter et al. 1994). On the basis of secondary structure prediction (Rost and Sander 1993) and helix wheel analysis (Schiffer and Edmundson 1967), we suggest that amino acids 256-270 fold as an amphipathic $\alpha$-helix, with one face consisting exclusively of hydrophobic amino acids and one face consisting primarily of hydrophilic amino acids (Fig. 5). We suggest further that the amphipathic $\alpha$-helix lies on the surface of the $\alpha$ carboxy-terminal domain, with the side chains of the hydrophobic amino acids interacting with the core of the domain and with the side chains of the hydrophilic amino acids solvent exposed and available to interact with other molecules (Fig. 5). According to these sugges- 
A

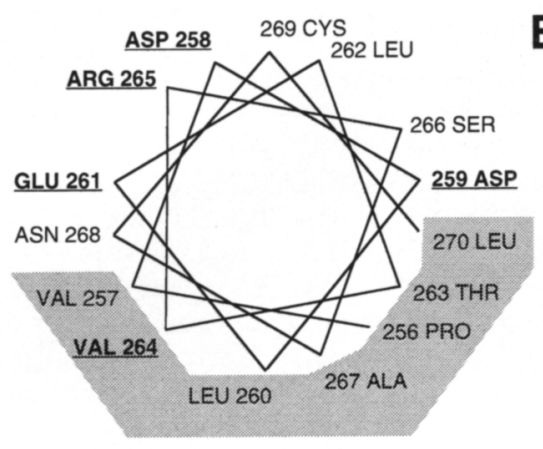

B

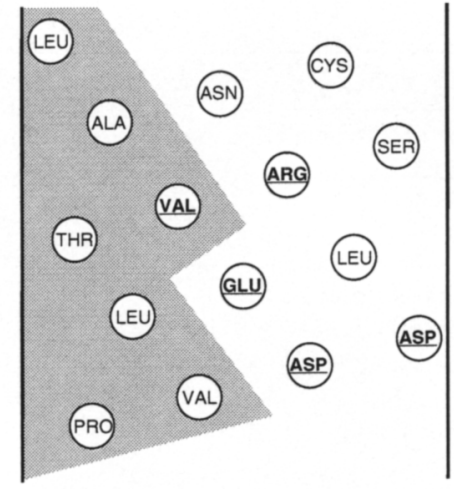

Figure 5. Proposed structure of the activation target. The hydrophobic and hydrophilic faces of the proposed surface amphipathic $\alpha$-helix are shaded and unshaded, respectively. The 5 amino acids at which substitutions conferring an $\mathrm{RpoA}^{\mathrm{pct}, \mathrm{CAP}}$ phenotype were obtained are underlined. (A) Helix-wheel representation (Schiffer and Edmundson 1967); (B) helix-net representation. tions, the 5 amino acids at which substitutions conferring an RpoA ${ }^{\text {pct,CAP }}$ phenotype were obtained-that is, Asp-258, Asp-259, Glu-261, Val-264, and Arg-265-form a cluster, with 4 of the 5 amino acids solvent exposed and with the most critical amino acid-that is, Glu261-centrally located and prominently solvent exposed (Fig. 5B).

\section{Function of the activation target}

Our results establish that (1) amino acids 258-265 of $\alpha$ constitute an activation target essential for CAP-dependent transcription at the lac promoter but not essential for CAP-independent transcription, (2) amino acid 261 is the most critical amino acid of the activation target, (3) amino acid 261 is distinct from the determinants for $\alpha$-DNA interaction, and (4) the activation target may fold as a surface amphipathic $\alpha$-helix. Previous results establish that amino acids 209-329 of $\alpha$ are in direct physical proximity to the activating region of CAP in the ternary complex of RNAP, CAP, and lac promoter (Chen et al. 1994|. We propose that transcriptional activation at the lac promoter requires protein-protein interaction between the activation target of $\alpha$ and the activating region of CAP. We suggest that at the lac promoter the entire 8 -amino-acid activation target of $\alpha$-folded as a surface amphipathic $\alpha$-helix-is in direct physical proximity to the entire 9-amino-acid activating region of CAP. We suggest further that at the lac promoter the most critical amino acid of the activation target of $\alpha$, Glu-261, makes direct side-chain contact with the most critical amino acid of the activating region of CAP, Thr-158 (see Niu et al. 1994).

Figure 6 presents a model that integrates our results and other recent results regarding transcriptional activation and RNAP structure and function (Kolb et al. 1993b; Ross et al. 1993; Zhou et al. 1993a,b; Blatter et al. 1994; Busby and Ebright 1994; Chen et al. 1994; Rao et al. 1994). The model proposes that at the lac promoter the $\alpha$ carboxy-terminal domain makes two interactions: (1) a protein-protein interaction involving the activation target of $\alpha$ and the activating region of CAP; and $(2)$ a nonspecific protein-DNA interaction involving determinants of $\alpha$ distinct from the activation target-or at least
A

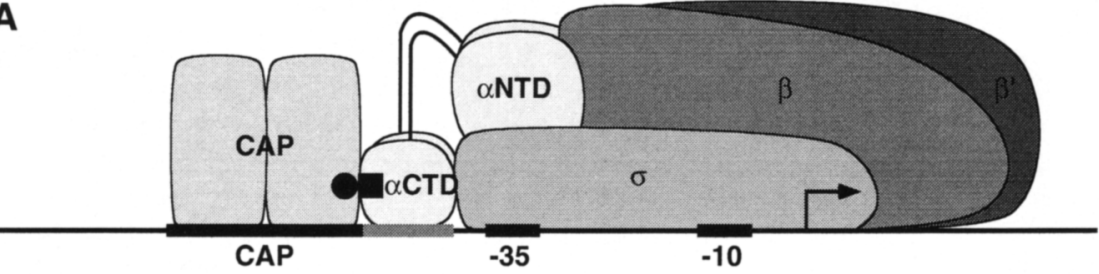

B

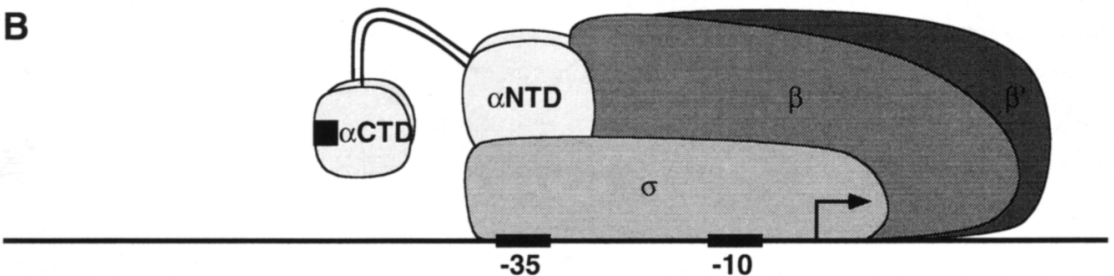

Figure 6. Proposed function of the activation target. $\alpha$ CTD and $\alpha$ NTD denote the $\alpha$ carboxy-terminal domain (two per RNAP molecule) and the $\alpha$ amino-terminal domain (two per RNAP molecule), respectively. (四) The activation target of $\alpha_{i}(\mathbf{O})$ the activating region of CAP. Black and shaded bars denote specific protein-DNA interactions and nonspecific protein-DNA interactions, respectively. Recent work regarding the domain organization and structure of $\alpha$ indicates that (1) the $\alpha$ carboxyterminal domain is an independently folded, independently dimerized DNAbinding domain, and (2) the $\alpha$ carboxy-terminal domain is connected to the remain$\operatorname{der}$ of $\alpha$ and, thus, to the remainder of RNAP, through $a \geqslant 13$-amino-acid unstructured and/or flexible linker $\geqslant 44 \AA$ if fully extended; Blatter et al. 1994). Alternative positioning of the $\alpha$ carboxy-terminal domain is proposed to be facilitated by the linker and, possibly, by bending of the intervening DNA. (A) CAP-dependent transcription at the lac promoter; $(B)$ CAP-independent transcription at the lacPUV5 promoter. 
Table 5. Bacterial strains

\begin{tabular}{lll}
\hline Strain & \multicolumn{1}{c}{ Genotype } & \multicolumn{1}{c}{ Source } \\
\hline XE4 & $l a c^{+} \Delta g a l 165$ thi & Ebright et al. (1984) \\
XE54 & lac ${ }^{+}$thi & this work \\
XE56 & lacPL8-UV5 thi & this work \\
\hline
\end{tabular}

All strains were constructed from strain X7029 (4lacX74 thi; Ebright 1985). The $\Delta$ gal165 marker was from bacteriophage

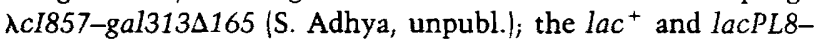
UV5 markers were from strains CA8439 (Sabourin and Beckwith 1974) and E8027 (Arditti et al. 1973), respectively.

distinct from Glu-261 - and promoter DNA between the DNA site for CAP and the -35 region. The proteinprotein interaction compensates for the absence in the lac promoter of a specific, high-affinity DNA site for $\alpha$. The protein-protein interaction increases the binding constant for RNAP-promoter interaction; in addition, the protein-protein interaction recruits the $\alpha$ carboxyterminal domain to DNA resulting in possibly activatory changes in RNAP conformation and RNAP-promoter organization.

This model accounts for the observation that in the presence of CAP, intact RNAP, but not an RNAP derivative lacking the $\alpha$ carboxy-terminal domain, protects the DNA segment between the DNA site for CAP and the -35 region from DNase I digestion (Kolb et al. 1993b). This model also accounts for the observation that CAP-dependent transcription requires structural integrity of the DNA segment between the DNA site for CAP and the -35 region (Ryu et al. 1994).

This model, in which $\alpha$ carboxy-terminal domain serves as an activator-binding and DNA-binding module flexibly tethered to the remainder of RNA polymerase, has similarities to developing models for function of coactivators and TBP-associated factors (TAFs) in eukaryotic transcription activation (Purnell et al. 1994; Tjian and Maniatis 1994; Verrijzer et al. 1994).

\section{Materials and methods}

Strains, media, and microbiological techniques

A list of $E$. coli $\mathrm{K}-12$ strains used in this work is presented in Table 5. Standard media were prepared and standard genetic manipulations were performed as described in Miller (1972). Lactose/ribose/tetrazolium/ampicillin indicator agar plates contained $1 \%$ ribose, $1 \%$ lactose, and $200 \mu \mathrm{g} / \mathrm{ml}$ of ampicillin.

\section{Plasmids}

A list of plasmids used in this work is presented in Table 6. Plasmids pREIl $\alpha$, pHTf $1 \alpha$, and derivatives encode $\alpha$ under control of the lppP-'lacPUV5 tandem promoter. Plasmid pHTT7a and derivatives encode $\alpha$ under control of the bacteriophage T7 gene 10 promoter. Each plasmid has a unique $X b a I$ site preceding the rpoA Shine-Delgarno sequence, a unique $E c o R I$ site at codon 168, a unique HindIII site at codon 229, a unique $S a c$ I site at codon 288 , and, in plasmids pREII $\alpha, \mathrm{pHTT} 7 \alpha$, and derivatives, a unique $B a m H I$ site immediately following the rpoA stop codon. For each plasmid, the DNA-nucleotide sequence of the entire $r p o A$ gene was verified.

\section{Mutagenesis}

Random mutagenesis was performed by error-prone PCR amplification of the 1-kb XbaI-BamHI rpoA segment of plasmid pREIl $\alpha$ (procedure of Zhou et al. 1991, 1993a). The primers used were PIN-XBA-PCR (5'-GGATAACAATTTCACACAGGAAACAG-3') and PIN-BAM-PCR (5'-CATTGCGTTCACGTCGTTGCTCAG-3'). The procedure yields all four transition substitutions $(A: T \rightarrow G: C, T: A \rightarrow C: G, C: G \rightarrow T: A$, and $G: C \rightarrow A: T)$, and at least four of eight transversion substitutions $(A: T \rightarrow T: A$ $\mathrm{T}: \mathrm{A} \rightarrow \mathrm{A}: \mathrm{T}, \mathrm{G}: \mathrm{C} \rightarrow \mathrm{T}: \mathrm{A}, \mathrm{C}: \mathrm{G} \rightarrow \mathrm{A}: \mathrm{T}$ ) (Table 2; Zhou et al. 1991, 1993a). Site-directed mutagenesis was performed by primer extension (procedure of Kunkel et al. 1991).

\section{Determination of levels of $\alpha$ in vivo}

To determine levels of $\alpha$ in cells grown on agar, 20-30 colonies were suspended in $1 \mathrm{ml}$ of M63 medium (Miller 1972), suspensions were adjusted to an $\mathrm{OD}_{600}$ of 0.6 , and aliquots of serial dilutions were analyzed by SDS-PAGE followed by immunoblotting. Immunoblotting was performed according to the procedure of Harlow and Lane (1988) using rabbit polyclonal anti- $\alpha$ antibody (prepared by Lampire Laboratories, Inc., Pipersville, PA), alkaline-phosphatase-conjugated goat anti-rabbit-immunoglobulin antibody (Bio-Rad, Inc.), and nitrocellulose membranes (Bio-Rad, Inc.).

\section{Measurement of transcription in vivo}

To measure transcription in vivo in the presence of $\alpha$ derivative $X$, the plasmid encoding $\alpha$ derivative $X$ was introduced into tester strains XE54 (lac ${ }^{+}$; CAP-dependent transcription) and XE56 (lacPL8-UV5; CAP-independent transcription), and the differential rates of $\beta$-galactosidase synthesis in the resulting plasmid-bearing strains were determined (method in Miller (1972), except that cultures were grown in Luria-Bertani (LB) medium containing $150 \mu \mathrm{g} / \mathrm{ml}$ of ampicillin and $5 \mathrm{~mm}$ isopropyl-thio- $\beta$-D-galactoside; three independent determinations].

\section{Preparation of $\alpha$}

RNAP $\alpha$ and derivatives were produced in strain BL21(DE3) (Studier et al. 1990; Novagen, Inc.) transformed with plasmid pHTT $7 \alpha$ and derivatives (production to the level of $\sim 30 \%$ of total cell protein). Following cell lysis by sonication, RNAP $\alpha$ and derivatives were localized $\sim 50 \%$ in the soluble cell fraction, and $\sim 50 \%$ in the insoluble cell fraction. RNAP $\alpha$ and derivatives were purified from the soluble cell fraction by polyethylenimine precipitation, ammonium sulfate precipitation, and hydrophobic interaction chromatography on phenyl-Toyopearl (Toyoba, Inc.) (modification of the procedure of Borukhov and Goldfarb 1993). Yields of RNAP $\alpha$ and derivatives were 3-4 $\mathrm{mg} /$ liter of culture, and purities were $>90 \%$. RNAP $\alpha$ and derivatives were stored in aliquots at $-20^{\circ} \mathrm{C}$ in $10 \mathrm{mM}$ Tris $-\mathrm{HCl}$ (pH 7.9), $150 \mathrm{mM} \mathrm{NaCl}, 0.5 \mathrm{mM}$ EDTA, and $50 \%$ glycerol.

Preparation of $\beta, \beta^{\prime}$, and $\sigma$

RNAP $\beta, \beta^{\prime}$ and $\sigma$ were prepared as described (Borukhov and Goldfarb 1993; Severinov et al. 1993).

\section{Reconstitution of RNAP holoenzyme}

RNAP holoenzyme and derivatives were reconstituted from purified subunits and were purified by size-exclusion chromatog- 
Table 6. Plasmids

\begin{tabular}{|c|c|c|}
\hline Plasmid & Relevant characteristics & Source \\
\hline pREII $\alpha$ & $\mathrm{Ap}^{\mathrm{R}} ;$ ori-pBR322; IppP-'lacPUV5-rpoA & Blatter et al. (1994) \\
\hline pREI $\alpha 258 \mathrm{~V}$ & $\mathrm{Ap}^{\mathrm{R}}$; ori-pBR322;IppP-1acPUV5-rpoA258V & this work \\
\hline pREII $261 \mathrm{G}$ & $\mathrm{Ap}^{\mathrm{R}}$; ori-pBR322;IppP-'lacPUV5-rpoA261G & this work \\
\hline pREII $\alpha 261 \mathrm{~K}$ & $\mathrm{Ap}^{\mathrm{R}}$; ori-pBR322; IppP-'lacPUV5-rpoA261K & this work \\
\hline pREII $\alpha 264 D$ & $\mathrm{Ap}^{\mathrm{R}} ;$ ori-pBR322; IppP-'lacPUV5-rpoA264D & this work \\
\hline pREII $\alpha 265 C$ & $\mathrm{Ap}^{\mathrm{R}} ;$ ori-pBR322; IppP-'lacPUV5-rpoA265C & this work \\
\hline pHTf $1 \alpha^{a}$ & $\mathrm{Ap}^{\mathrm{R}}$; ori-pBR322; ori-f1; IppP-'lacPUV5-rpoA & this work \\
\hline pHTfl $1 \alpha 255 \mathrm{~A}$ & $\mathrm{Ap}^{\mathrm{R}}$; ori-pBR322; ori-f1; IppP-'lacPUV5-rpoA255A & this work \\
\hline pHTf $1 \alpha 256 \mathrm{~A}$ & $\mathrm{Ap}^{\mathrm{R}}$; ori-pBR322; ori-f1; IppP-1acPUV5-rpoA256A & this work \\
\hline pHTfl $\alpha 257 \mathrm{~A}$ & $\mathrm{Ap}^{\mathrm{R}}$; ori-pBR322; ori-f1; IppP-'lacPUV5-rpoA257A & this work \\
\hline $\mathrm{pHTf} l \alpha 258 \mathrm{~A}$ & $\mathrm{Ap}^{\mathrm{R}} ;$ ori-pBR322; ori-f1; IppP-'lacPUV5-IpoA258A & this work \\
\hline pHTfl $1 \alpha 259 \mathrm{~A}$ & $\mathrm{Ap}^{\mathrm{R}}$; ori-pBR322; ori-f1; IppP-'lacPUV5-rpoA259A & this work \\
\hline pHTfl $\alpha 260 A$ & $\mathrm{Ap}^{\mathrm{R}}$; ori-pBR322; ori-f1; IppP-'lacPUV5-rpoA260A & this work \\
\hline pHTfl $\alpha 261 \mathrm{~A}$ & $\mathrm{Ap}^{\mathrm{R}}$; ori-pBR322; ori-f1; IppP-'lacPUV5-IpoA261A & this work \\
\hline pHTfl $\alpha 262 \mathrm{~A}$ & $\mathrm{Ap}^{\mathrm{R}}$; ori-pBR322; ori-f1; IppP-lacPUV5-rpoA262A & this work \\
\hline pHTf $1 \alpha 263 \mathrm{~A}$ & $\mathrm{Ap}^{\mathrm{R}}$; ori-pBR322; ori-f1; IppP-lacPUV5-rpoA263A & this work \\
\hline pHTf $1 \alpha 264 A$ & $\mathrm{Ap}^{\mathrm{R}}$; ori-pBR322; ori-f1; IppP-lacPUV5-rpoA264A & this work \\
\hline pHTf $1 \alpha 265 A$ & $\mathrm{Ap}^{\mathrm{R}}$; ori-pBR322; ori-f1; IppP-'IacPUV5-rpoA265A & this work \\
\hline pHTf $1 \alpha 266 A$ & $\mathrm{Ap}^{\mathrm{R}}$; ori-pBR322; ori-f1; IppP-'lacPUV5-rpoA266A & this work \\
\hline pHTf $1 \alpha 268 \mathrm{~A}$ & $\mathrm{Ap}^{\mathrm{R}}$; ori-pBR322; ori-f $1 ;$ IppP-'lacPUV5-rpoA268A & this work \\
\hline pHTfl $\alpha 269 A$ & $\mathrm{Ap}^{\mathrm{R}}$; ori-pBR322; ori-f1; IppP-'lacPUV5-rpoA269A & this work \\
\hline pHTf $1 \alpha 270 A$ & $\mathrm{Ap}^{\mathrm{R}} ;$ ori-pBR322; ori-f1; IppP-'lacPUV5-rpoA270A & this work \\
\hline pHTT7 $\alpha$ & $\mathrm{Ap}^{\mathrm{R}} ;$ ori-pBR322; $\phi 10 P-r p o A$ & Blatter et al. (1994) \\
\hline pHTT7 $\alpha 261 \mathrm{G}$ & $\mathrm{Ap}^{\mathrm{R}} ;$ ori-pBR322; $10 P-r p o A 261 G$ & this work \\
\hline pHTT7 $\alpha 261 \mathrm{~K}$ & $\mathrm{Ap}^{\mathrm{R}} ;$ ori-pBR $322 ; \phi 10 P-r p o A 261 \mathrm{~K}$ & this work \\
\hline pMKSe2 & $\mathrm{Ap}^{\mathrm{R}} ;$ ori-pBR322; $1 a c P-r p o B$ & Severinov et al. (1993) \\
\hline pT7 $\beta^{\prime}$ & $\mathrm{Ap}^{\mathrm{R}} ;$ ori-pBR322; $\phi 10 P-r p o C$ & Zalenskaya et al. (1990) \\
\hline pMRG8 & $\mathrm{Ap}^{\mathrm{R}} ;$ ori-pBR322; $\lambda P_{\mathrm{L}} \mathrm{O}_{\mathrm{L}}-r p o D$ & Gribskov and Burgess (1983) \\
\hline pBR-203-lac & $\mathrm{Ap}^{\mathrm{R}}$; ori-pBR322; lac $P^{+}$ & Malan et al. (1984) \\
\hline pBR-203-lacPUV5 & $\mathrm{Ap}^{\mathrm{R}}$; ori-pBR322; lacPUV5 & Zhou et al. (1993a) \\
\hline
\end{tabular}

aplasmid pHTfl $\alpha$ was constructed by insertion of the 0.5-kb BgIII-BgllI ori-f1 segment of plasmid pND118B (Heitman et al. 1989) at the BamHI site of plasmid pREII $\alpha$. Replication initiating at ori-f1 yields single-stranded DNA containing the antisense strand of $r p o A$.

raphy on Superose 6 (Pharmacia, Inc.) followed by anion-exchange chromatography on Mono Q (Pharmacia, Inc.) (procedure of Borukhov and Goldfarb 1993). RNAP and derivatives were stored in aliquots at $-20^{\circ} \mathrm{C}$ in $10 \mathrm{~mm}$ Tris- $\mathrm{HCl}(\mathrm{pH} 7.9)$, $200 \mathrm{~mm} \mathrm{NaCl}, 0.5 \mathrm{~mm}$ EDTA, and $50 \%$ glycerol.

\section{Mass spectrometry}

RNAP $\alpha$ and derivatives, prepared as described above, or prepared from RNAP and derivatives by denaturing centrifugal ultrafiltration [Centricon-100 filter units (Amicon, Inc.); 1000g; for $40 \mathrm{~min}$ at $4^{\circ} \mathrm{C}$ in $8 \mathrm{M}$ guanidine- $\mathrm{HCl}, 50 \mathrm{~mm}$ Tris- $\mathrm{HCl} / \mathrm{pH}$ $8.0 \mid, 150 \mathrm{mM} \mathrm{KCl}$, and $1 \mathrm{~mm}$ EDTA], were digested with endoproteinase Glu-C, and products were analyzed by MALDI mass spectrometry. Reaction mixtures $(30 \mu \mathrm{l})$ contained $10 \mu \mathrm{M}$ RNAP $\alpha$ or derivative, $0.2 \mu \mathrm{g}$ of endoproteinase Glu-C (Boehringer Mannheim $\mathrm{GmbH}$ ), $50 \mathrm{~mm}$ ammonium bicarbonate $(\mathrm{pH}$ 8.0 ), and $15 \mathrm{mM} \mathrm{NaCl}$. After $1 \mathrm{hr}$ at $22^{\circ} \mathrm{C}, 1-\mu \mathrm{l}$ aliquots were withdrawn, mixed with $9 \mu \mathrm{l}$ of $50 \mathrm{mM} \alpha$-cyano-4-hydroxycinnamic acid in formic acid/water/isopropanol (1:3:2, vol/vol/ vol), and analyzed by MALDI mass spectrometry (procedure of Beavis and Chait 1990).

\section{Transcription experiments}

Abortive initiation in vitro transcription experiments were performed as described by Zhang et al. (1992). Experiments were performed using as templates 203-bp EcoRI-EcoRI DNA frag- ments of plasmids pBR-203-lac and pBR-203-lacPUV5. Reaction mixtures contained $(25 \mu \mathrm{l}): 150 \mathrm{nM}$ RNAP or RNAP derivative, 0 or $40 \mathrm{nM}$ CAP (purified as described by Zhang et al. 1991), 0.5 nM DNA fragment, $0.5 \mathrm{~mm}$ ApA (ICN Biomedicals, Inc.), $50 \mathrm{nM}$ $\left[\alpha^{-32}\right]$ UTP $(30 \mathrm{~Bq} / \mathrm{fmole}), 40 \mathrm{mM}$ Tris- $\mathrm{HCl}(\mathrm{pH} 8.0), 100 \mathrm{mM} \mathrm{KCl}$, $10 \mathrm{mM} \mathrm{MgCl}, 1 \mathrm{~mm}$ dithiothreitol, $5 \%$ glycerol, and $0.2 \mathrm{~mm}$ cAMP. Reaction components except ApA and $\left[\alpha^{-32} \mathrm{P}\right]$ UTP were pre-equilibrated for $10 \mathrm{~min}$ at $37^{\circ} \mathrm{C}$. Reactions were initiated by addition of ApA and $\left[\alpha^{-32} \mathrm{P}\right] \mathrm{UTP}$ and were allowed to proceed for $15 \mathrm{~min}$ at $37^{\circ} \mathrm{C}$. Reactions were terminated by addition of $5 \mu \mathrm{l}$ $0.5 \mathrm{M}$ EDTA. The reaction product $\left[{ }^{32} \mathrm{P}\right] \mathrm{ApApUpU}$ was resolved by paper chromatography in water/saturated ammonium sulfate/isopropanol $(18: 80: 2, \mathrm{vol} / \mathrm{vol})$ and quantified by Cerenkov counting.

\section{DNA-binding experiments}

Electrophoretic mobility shift DNA-binding experiments were performed using a 19-bp DNA fragment containing a specific DNA site for $\alpha$ (positions -57 to -47 of the $\operatorname{rrnB}$ P1 promoter upstream element; 5'-TCAGAAAATTATTTTCGGG-3'/5' -CCCGAAAATAATTTTCTGA-3'). Reaction mixtures contained $(20 \mu \mathrm{l}): 0$ to $75 \mu \mathrm{M} \alpha$ or derivative, $125 \mathrm{nM}\left[{ }^{32} \mathrm{P}\right)$-labeled DNA fragment $(10 \mathrm{~Bq} /$ pmole; prepared as described by Ebright et al. 1989), $10 \mathrm{~mm}$ MOPS-NaOH (pH 7.0), $50 \mathrm{~mm} \mathrm{NaCl}, 10 \mathrm{~mm}$ $\mathrm{MgCl}_{2}$, and $5 \%$ glycerol. Reaction mixtures were incubated for $1 \mathrm{hr}$ at $30^{\circ} \mathrm{C}$. Reaction mixtures then were applied to $5 \%$ polyacrylamide, $2.7 \%$ glycerol slab gels $(9 \times 7 \times 0.15 \mathrm{~cm})$, and electro- 
phoresed in $45 \mathrm{mM}$ Tris-borate (pH 8.0), $5 \mathrm{mM} \mathrm{MgCl}_{2}$, and 0.1 mM EDTA $\left(20 \mathrm{~V} / \mathrm{cm} ; 20 \mathrm{~min}\right.$ at $\left.4^{\circ} \mathrm{C}\right)$. Following electrophoresis, gels were dried and autoradiographed. Radioactivity was quantified by PhosphorImager analysis (Molecular Dynamics, model $425 E$ ). Equilibrium binding constants were calculated as described by Gunasekera et al. (1992).

Electrophoretic mobility shift DNA-binding experiments yield results for $\alpha$-DNA interaction that are quantitatively equivalent to those of DNase I footprinting (cf. Ross et al. 1993; Blatter et al. 1994). Control experiments establish that the observed interactions are specific. Thus, under identical conditions, wild-type $\alpha$, [Gly-261] $\alpha$, and [Lys-261] $\alpha$ exhibit $\sim 30$-fold lower affinities for DNA fragments not containing a specific DNA site for $\alpha\left(5^{\prime}\right.$-CGCCGATTGCGCAATCCAGC- $3^{\prime} / 5^{\prime}$-GC. TGGATTGCGCAATCGGCG-3'; 5'-CGCCTATGACGTCATCCAGC-3' $/ 5^{\prime}$-GCTGGATGACGTCATAGGCG-3') and $\sim 10-$ fold lower affinities for a DNA fragment containing a scrambled version of the specific DNA site for $\alpha\left(5^{\prime}\right.$-TCAGTTTTATTAAAACGGG-3' $/ 5^{\prime}$-CCCGTTTTAATAAAACTGA-3'.

For each preparation of $\alpha$ or derivative, the fraction of molecules active in sequence-specific DNA binding was determined by titration of the DNA fragment under stoichiometric binding conditions (100 $\mu \mathrm{M}$ DNA fragment; $50-400 \mu \mathrm{M} \alpha$ or derivative); all data are reported in terms of molar concentrations of active dimers.

\section{Acknowledgments}

We thank S. Adhya for bacteriophage $\lambda c I 857-$ gal313D165 and M. Russel for plasmid pND118B. We acknowledge R. Gourse, W. Ross, and S. Adhya for important discussions. This work was supported by National Institutes of Health grants (GM41376 to R.H.E.; GM30717 to A.G.; and GM38274 and RR00862 to B.C.).

The publication costs of this article were defrayed in part by payment of page charges. This article must therefore be hereby marked "advertisement" in accordance with 18 USC section 1734 solely to indicate this fact.

\section{References}

Arditti, R., T. Grodzicker, and J. Beckwith. 1973. Cyclic adenosine monophosphate-independent mutants of the lactose operon of Escherichia coli. I. Bacteriol. 114: 652-655.

Beavis, R. and B. Chait. 1990. High-accuracy molecular mass determination of proteins using matrix-assisted laser desorption mass spectrometry. Anal. Chem. 62: 1836-1840.

Beckwith, J. 1978. lac: The genetic system. In The operon (ed. J. Miller and W. Reznikoff|, pp. 11-30. Cold Spring Harbor Laboratory, Cold Spring Harbor, New York.

Beckwith, J., T. Grodzicker, and R. Arditti. 1972. Evidence for two sites in the lac promoter region. J. Mol. Biol. 69: 155160.

Bell, A., S. Buckel, J. Groarke, J. Hope, D. Kingsley, and M. Hermodson. 1986. The nucleotide sequence of the $r b s D$, rbsA, and $r b s C$ genes of Escherichia coli K12. J. Biol. Chem. 261: 7652-7658.

Bell, A., K. Gaston, R. Williams, K. Chapman, A. Kolb, H. Buc, S. Minchin, J. Williams, and S. Busby. 1990. Mutations that alter the ability of the Escherichia coli cyclic AMP receptor protein to activate transcription. Nucleic Acids Res. 18: 7243-7250.

Blatter, E., W. Ross, H. Tang, R. Gourse, and R. Ebright. 1994. Domain organization of RNA polymerase $\alpha$ subunit: C-terminal 85 amino acids constitute an independently folded domain capable of dimerization and DNA binding. Cell 78: 889-896.
Borukhov, S. and A. Goldfarb. 1993. Recombinant Escherichia coli RNA polymerase: purification of individually overexpressed subunits and in vitro assembly. Protein Exp. Purif. 4: 503-511.

Burgess, R. 1976. Purification and physical properties of $E$. coli RNA polymerase. In RNA polymerase (ed. R. Losick and $\mathrm{M}$. Chamberlin\}, pp. 69-100. Cold Spring Harbor Laboratory, Cold Spring Harbor, New York.

Busby, S. and R. Ebright. 1994. Promoter structure, promoter recognition, and transcription activation in prokaryotes. Cell (in press).

Chamberlin, M. 1976. RNA polymerase-An overview. In RNA polymerase (ed. R. Losick and M. Chamberlin), pp. 17-67. Cold Spring Harbor Laboratory, Cold Spring Harbor, New York.

Chen, Y., Y. Ebright, and R. Ebright. 1994. Identification of the target of a transcription activator protein by protein-protein photocrosslinking. Science 265: 90-92.

Chothia, C. 1976. The nature of the accessible and buried surfaces in proteins. I. Mol. Biol. 105: 1-14.

Cunningham, B. and J. Wells. 1989. High-resolution epitope mapping of hGH-receptor interactions by alanine-scanning mutagenesis. Science 244: 1081-1085.

- 1993. Comparison of a structural and a functional epitope. I. Mol. Biol. 234: 554-563.

Dickson, R., J. Abelson, P. Johnson, W. Reznikoff, and W. Barnes. 1977. Nucleotide sequence changes produced by mutations in the lac promoter of Escherichia coli. J. Mol. Biol. 111: 65-75.

Ebright, R. 1985. Use of "loss-of-contact" substitutions to identify residues involved in an amino acid-base pair contact: Effect of substitution of Gln18 of Lac repressor by Gly, Ser, and Leu. I. Biomol. Struct. Dynam. 3: 281-297.

- 1993. Transcription activation at Class I CAP-dependent promoters. Mol. Microbiol. 8: 797-802.

Ebright, R., P. Cossart, B. Gicquel-Sanzey, and J. Beckwith. 1984. Mutations that alter the DNA sequence specificity of the catabolite gene activator protein of $E$. coli. Nature 311: 232-235.

Eschenlauer, A. and W. Reznikoff. 1991. Escherichia coli catabolite gene activator protein mutants defective in positive control of lac operon transcription. I. Bacteriol. 173: 5024 5029.

Gilbert, W. 1976. Starting and stopping sequences for the RNA polymerase. In RNA polymerase (ed. R. Losick and $\mathbf{M}$. Chamberlin), pp. 193-206. Cold Spring Harbor Laboratory, Cold Spring Harbor, New York.

Goff, C. 1984. Coliphage-induced ADP-ribosylation of Escherichia coli RNA polymerase. Methods Enzymol. 106: 418429.

Gribskov, M. and R. Burgess. 1983. Overexpression and purification of the sigma subunit of Escherichia coli RNA polymerase. Gene 26: 109-118.

Gunasekera, A., Y. Ebright, and R. Ebright. 1992. DNA-sequence determinants for binding of the Escherichia coli catabolite gene activator protein (CAP). I. Biol. Chem. 267: 14713-14720.

Harlow, E. and D. Lane. 1988. Antibodies: A laboratory manual, Cold Spring Harbor Laboratory, Cold Spring Harbor, New York.

Hayward, R., K. Igarashi, and A. Ishihama. 1991. Functional specialization within the alpha-subunit of Escherichia coli RNA polymerase. $/$. Mol. Biol. 221: 23-29.

Heitman, J., J. Treisman, N. Davis, and M. Russel. 1989. Cassettes of the $\mathrm{fl}$ intergenic region. Nucleic Acids Res. 17: 4413 . 
Igarashi, K. and A. Ishihama. 1991. Bipartite functional map of the $E$. coli RNA polymerase alpha subunit: Involvement of the $C$-terminal region in transcription activation by cAMPCRP. Cell 65: 1015-1022.

Igarashi, K., N. Fujita, and A. Ishihama. 1991. Identification of a subunit assembly domain in the alpha subunit of Escherichia coli RNA polymerase. I. Mol. Biol. 218: 1-6.

Iida, A., S. Harayama, T. Iino, and G. Hazelbauer. 1984. Molecular cloning and characterization of genes required for ribose transport and utilization in Escherichia coli K-12. I. Bacteriol. 158: 674-682.

Janin, J. 1979. Surface and inside volumes in globular proteins. Nature 277: 491-492.

Jin, L., B. Fendly, and J. Wells. 1992. High resolution functional analysis of antibody-antigen interactions. I. Mol. Biol. 226: 851-865.

Kelley, R. and M. O'Connell. 1993. Thermodynamic analysis of an antibody functional epitope. Biochemistry 32: 68286835

Kolb, A., S. Busby, H. Buc, and S. Adhya. 1993a. Transcriptional regulation by cAMP and its receptor protein. Annu. Rev. Biochem. 62: 749-795.

Kolb, A., K. Igarashi, A. Ishihama, M. Lavigne, M. Buckle, and H. Buc. 1993b. E. coli RNA polymerase, deleted in the C-terminal part of its alpha-subunit, interacts differently with the cAMP-CRP complex at the lacP1 and at the galP1 promoter. Nucleic Acids Res. 21: 319-326.

Kunkel, T., K. Bebenek, and J. McClary. 1991. Efficient sitedirected mutagenesis using uracil-containing DNA. Methods Enzymol. 204: 125-138.

Lopilato, J., J. Garwin, S. Emr, T. Silhavy, and J. Beckwith. 1984. D-Ribose metabolism in Escherichia coli K-12: Genetics, regulation, and transport. J. Bacteriol. 158: 665-673.

Malan, T.P., A. Kolb, H. Buc, and W. McClure. 1984. Mechanism of CRP-cAMP activation of lac operon transcription initiation: Activation of the Pl promoter. J. Mol. Biol. 180: 881-909.

Miller, J. 1972. Experiments in molecular genetics, Cold Spring Harbor Laboratory, Cold Spring Harbor, New York.

Niu, W., Y. Zhou, Q. Dong, Y. Ebright, and R. Ebright. 1994. Characterization of the activating region of Escherichia coli catabolite gene activator protein (CAP): I. Saturation and alanine-scanning mutagenesis. J. Mol. Biol. 243: 595-602.

Purnell, B., P. Emanuel, and D. Gilmour. 1994. TFIID sequence recognition of the initiator and sequences farther down. stream in Drosophila class II genes. Genes \& Dev. 8: 830 842.

Rao, L., W. Ross, J.A. Appleman, T. Gaal, S. Leirmo, P. Schlax, M.T. Record, and R. Gourse. 1994. Factor independent activation of $r r n B$ Pl: An "extended" promoter with an upstream element that dramatically increases promoter strength. I. Mol. Biol. 235: 1421-1435.

Reznikoff, W. 1992. Catabolite gene activator protein activation of lac transcription. J. Bacteriol. 174: 655-658.

Riftina, F., E. DeFalco, and J. Krakow. 1990. Effects of an anti- $\alpha$ monoclonal antibody on interaction of Escherichia coli RNA polymerase with lac promoters. Biochemistry 29: $4440-4446$

Ross, W., K. Gosink, J. Salomon, K. Igarashi, C. Zou, A. Ishihama, K. Severinov, and R. Gourse. 1993. A third recognition element in bacterial promoters: DNA binding by the alpha subunit of RNA polymerase. Science 262: 1407-1413.

Rost, B. and C. Sander. 1993. Prediction of protein secondary structure at better than $70 \%$ accuracy. J. Mol. Biol. 232: 584 598.

Ryu, S., S. Garges, and S. Adhya. 1994. An arcane role of DNA in transcription activation. Proc. Natl. Acad. Sci. 91: 85828586.

Sabourin, D. and J. Beckwith. 1975. Deletion of the Escherichia coli crp gene. I. Bacteriol. 122: 338-340.

Schiffer, M. and A. Edmundson. 1967. Use of helical wheels to represent the structures of protein and to identify segments with helical potential. Biophys. I. 7: 121-135.

Schultz, S., G. Shields, and T. Steitz. 1991. Crystal structure of a CAP-DNA complex: The DNA is bent by 90 degrees. Science 253: 1001-1007.

Severinov, K., M. Soushko, A. Goldfarb, and V. Nikiforov. 1993. Rifampicin region revisited: New rifampicin-resistant and streptolydigin-resistant mutants of the $\beta$ subunit of Escherichia coli RNA polymerase. J. Biol. Chem. 268: 1482014825.

Silverstone, A., R. Arditti, and B. Magasanik. 1970. Cataboliteinsensitive revertants of lac promoter mutants. Proc. Natl. Acad. Sci. 66: 773-779.

Studier, F.W., A. Rosenberg, J. Dunn, and J. Dubendorff. 1990. Use of T7 RNA polymerase to direct expression of cloned genes. Methods Enzymol. 185: 60-89.

Tjian, R. and T. Maniatis. 1994. Transcriptional activation: a complex puzzle with few easy pieces. Cell 77: 5-8.

Venezia, N.D. and J. Krakow. 1990. Effects of anti- $\alpha$ monoclonal antibodies on initiation and elongation by the Escherichia coli RNA polymerase. J. Biol. Chem. 265: 8122-8126.

Verrijzer, C.P., K. Yokomori, J.-L. Chen, and R. Tjian. 1994. Drosophila $\mathrm{TAF}_{\mathrm{II}} 150$ : Similarity to yeast gene TSM-1 and specific binding to core promoter DNA. Science 264: 933941.

von Hippel, P., T. Yager, and S. Gill. 1992. Quantitative aspects of the transcription cycle in Escherichia coli. In Transcriptional regulation (ed. S. McKnight and K. Yamamoto), pp. 179-201. Cold Spring Harbor Laboratory, Cold Spring Harbor, New York.

Wells, J. 1991. Systematic mutational analysis of protein-protein interfaces. Methods Enzymol. 202: 390-411.

Zalenskaya, K., I. Lee, N.G. Chandrasekhar, Y.K. Shin, M. Slutsky, and A. Goldfarb. 1990. Recombinant RNA polymerase: Inducible overexpression, purification and assembly of Escherichia coli rpo gene products. Gene 89: 7-12.

Zhang, X., A. Gunasekera, Y. Ebright, and R. Ebright. 1991. Derivatives of CAP having no solvent-accessible cysteine residues, or having a unique solvent-accessible cysteine residue at amino acid 2 of the helix-turn-helix motif. I. Biomol. Struct. Dynam. 9: 463-473.

Zhang, X., Y. Zhou, Y. Ebright, and R. Ebright. 1992. Catabolite gene activator protein (CAP) is not an "acidic activating region" transcription activator protein: Negatively charged amino acids of CAP that are solvent-accessible in the CAPDNA complex play no role in transcription activation at the lac promoter. J. Biol. Chem. 267: 8136-8139.

Zhou, Y., X. Zhang, and R. Ebright. 1991. Random mutagenesis of gene-sized DNA molecules by use of PCR with Taq DNA polymerase. Nucleic Acids Res. 19: 6052.

. 1993a. Identification of the activating region of CAP: Isolation and characterization of mutants of CAP specifically defective in transcription activation. Proc. Natl. Acad. Sci. 90: 6081-6085.

Zhou, Y., S. Busby, and R. Ebright. 1993b. Identification of the functional subunit of a dimeric transcription activator protein by use of "oriented heterodimers." Cell 73: 375-379.

Zou, C., N. Fujita, K. Igarashi, and A. Ishihama. 1992. Mapping the cAMP receptor protein contact site on the alpha subunit of Escherichia coli RNA polymerase. Mol. Microbiol. 6: 2599-2605. 


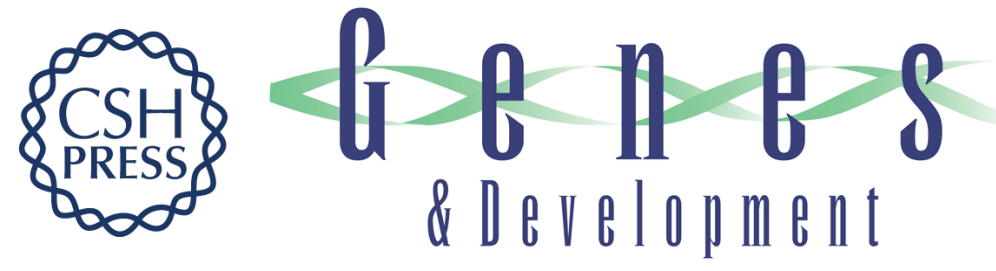

\section{Location, structure, and function of the target of a transcriptional activator protein.}

H Tang, K Severinov, A Goldfarb, et al.

Genes Dev. 1994, 8:

Access the most recent version at doi:10.1101/gad.8.24.3058

References This article cites 57 articles, 20 of which can be accessed free at:

http://genesdev.cshlp.org/content/8/24/3058.full.html\#ref-list-1

License

Email Alerting

Service

Receive free email alerts when new articles cite this article - sign up in the box at the top right corner of the article or click here.

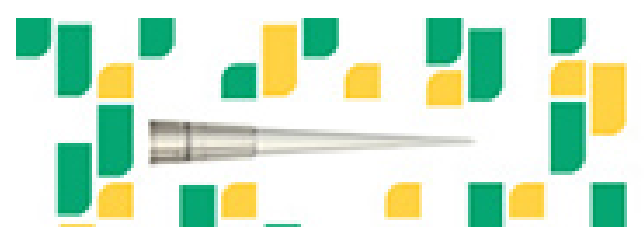

Focused on your science.

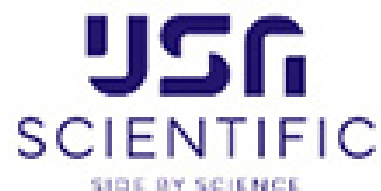

Copyright (c) Cold Spring Harbor Laboratory Press 